\title{
A Survey of The Studies on Children's Song Accompaniment and Playing and Singing Course of Preschool Education Major in Higher Vocational Education in China
}

\author{
Lin ZiXuan ${ }^{1}$, Karthiyaini Devarajoo ${ }^{2}$ \\ ${ }^{1}$ Guangxi College for Preschool Education, 6 Fengxiang Road, Nanning City, Guangxi Province, China \\ ${ }^{2}$ Faculty of Business, Information and Human Sciences Infrastructure University Kuala Lumpur, Malaysia
}

\begin{abstract}
With the in-depth reform of quality education in China, preschool education, as a basic education, is becoming more and more popular. The enrollment of preschool education in Higher Vocational Colleges in various regions is expanding and developing. In the skill courses of preschool education, Children's Song Accompaniment, Playing and Singing is a compulsory course. This course is not only the skill of playing the piano, but also an important tool and means for kindergarten teachers to communicate with children. For kindergarten teachers, children's song accompaniment and playing and singing teaching ability is the most basic professional skill of an excellent kindergarten teacher. However, at present, the training of this course in higher vocational colleges can not fully meet the professional needs of college students after graduation. This study, through the collation and analysis of existing literature, discusses the problems and difficulties faced by piano lecturers majoring in preschool education in Higher Vocational Colleges in ensuring that the teaching objectives, teaching methods and teaching practice of Children's Song Accompaniment, Playing and Singing course meet the standards stipulated by the Ministry of education of China, so as to help students better master this course and apply it flexibly in practical teaching in their future jobs.
\end{abstract}

Keywords: Preschool education, piano education, music education, Children's Song Accompaniment, Playing and Singing

\section{INTRODUCTION}

Children's song accompaniment and playing and singing course is an important part of the professional skills course of preschool education in higher vocational colleges. It is also the main means and channel to cultivate students' music teaching application ability facing the practical skills needs of kindergarten vocational posts (Yuan, 2017).Children's song accompaniment and singing ability is a necessary professional skill for a qualified preschool teacher. In the process of kindergarten education, the playing and singing ability of kindergarten teachers will affect the formation of a good music atmosphere and the creation of a good music environment, which can not only enrich children's spiritual world, but also stimulate children's potential to learn music and improve children's interest in music (Fan, 2021)

At present, the teaching of children's song accompaniment and playing and singing is facing some practical problems, such as the lack of quality education, the imperfect teaching system, the derailment between theory and practice and so on (Ruofei. 2020). The purpose of this study is to promote the education and teaching reform of children's song accompaniment and playing and singing courses, improve learning efficiency and quality, and actively innovate the talent training mode of Teacher Education (Ministry of education, 2017).

In music teaching activities in kindergartens, children's song accompaniment and playing and singing occupies an important position in the classroom in a distinctive and flexible teaching form, mainly through the perfect combination of piano accompaniment and nursery rhyme singing to have a good artistic dialogue with children (Yuan, 2017).Therefore, for students majoring in preschool education, nursery rhyme accompaniment and playing and singing are not just playing and singing by themselves, but a means to realize multi-directional communication and interaction with children based on the needs of professional posts in early childhood education (Xiaoqin, 2020).

\section{RESEARCH METHOD}

This paper makes a systematic literature review (SLR) on the teaching methods of children's song accompaniment and playing and singing in Chinese preschool education, and emphasizes some improvement methods of promoting playing and singing teaching through reflective teaching. It is hoped to provide reference for the teaching reform of playing and singing, so as to promote the development of children's song playing and singing, and comprehensively improve students' ability of children's song accompaniment arrangement and playing and singing. 


\section{CHALLENGES FACED BY CHILDREN'S SONG ACCOMPANIMENT AND PLAYING AND SINGING COURSES IN PRESCHOOL EDUCATION}

In recent years, due to the popularity of preschool education, piano teachers continue to carry out teaching reform in order to improve teaching quality, and point out that there is a gap between the current situation of this course and the curriculum standard.

\subsection{Teaching objectives}

The main training goal of keyboard courses in preschool education is to provide kindergarten teachers who are competent for children's music education activities (Fan, 2021). During the students' internship in the kindergarten, the kindergarten principals reflected that there was a big gap between the actual playing and singing ability of many preschool education interns and graduates and the work demand, which had a great impact on the quantity and quality of preschool education students' employment (Xuanxuan, 2021).

Therefore, for students majoring in preschool education, the completion of teaching objectives can improve students to become a qualified kindergarten teacher (Wang, 2019).

However, at present, due to the great differences in the foundation of preschool education students in higher vocational schools, and most colleges and universities fail to keep up with the pace of reform in time, they lack due attention and specific training programs in the cultivation of children's song playing and singing ability of preschool education students, resulting in the low children's song playing and singing ability of the students (Min, 2021).

In addition, most of the students majoring in preschool education in higher vocational colleges have not studied music or piano before entering the school (Rongxing, 2019), and most of the students in higher vocational colleges adopt the $2+1$ teaching mode, that is, they study in school for two years and go out for internship for one year, so the two-year piano learning time is very limited and tense (Yuzhe, 2020).There is a deviation of discipline understanding in preschool education (Tian, 2021). Most students are not clear about their major and training objectives, and do not understand the importance of children's song accompaniment and playing and singing courses, resulting in low learning enthusiasm (Debei, 2019).Moreover, students lack clear provisions on the skills and abilities that preschool teachers need to master, and the effect of future work practice is not clear (Rongxing, 2019).

Due to the differences in knowledge structure and culture, preschool college students in higher vocational colleges generally lack of basic music knowledge, and lack common knowledge in children's music (Yao, 2021). For adult college students, in the process of learning piano, the reaction ability and coordination of fingers are not good enough, and the perception and understanding ability of music is weak (Hualiang, 2020). Therefore, it is a great challenge for students and teachers to master children's song accompaniment and playing and singing skills in just one or two years (Weijie, 2020). Students are not confident in the process of playing and singing, which is usually characterized by pause, nervousness, confusion and confusion. They always doubt their ability of playing and singing, and are unable to smoothly complete children's song accompaniment and playing and singing. Various difficulties lead to students' failure to complete the basic teaching objectives as required (Hui, 2020).In addition, due to the poor music perception and expression of students themselves, their learning of children's songs is only to learn basic music knowledge and playing and singing skills. They will not analyze the melody of songs, nor can they clearly express the specific contents and emotions they need to convey (Xinchao, 2020).

\subsection{Curriculum}

The goal of piano teaching in preschool education is not to cultivate professional talents of performance, but to cultivate students to master the skills of piano playing, and use this skill to serve teaching, cultivate children's sentiment in the teaching process, and arouse their interest in learning and love of music (Guofang, 2021).

The children's song accompaniment and playing and singing course is a highly comprehensive course, including piano playing technology, music artistry, creativity, music foundation and music comprehensiveness (Yao, 2021). By learning this course, students can master the comprehensive ability of children's song accompaniment arrangement and playing and singing on the basis of mastering piano playing skills, By effectively combining playing and singing, students not only master the theoretical basic ability of children's song accompaniment, but also have the ability of children's song accompaniment and playing and singing, which can enable students to meet the needs of future preschool teachers (Fan, 2021).

However, among the music categories of preschool education major in higher vocational colleges, music theory, piano and vocal music are taught independently (Xia, 2019).Due to the division of courses, students have a short time to learn theoretical knowledge. Therefore, they do not have a reliable grasp of music theory knowledge, and they also know a little about the harmony knowledge, which brings some difficulties to teaching.The lack of organic links among the courses makes it difficult to carry out comprehensive training, which affects the cultivation of students' playing and singing ability (Tonghui, 2019).In the process of playing and singing, we should focus on singing, but at present, the students' playing foundation and vocal sound foundation are weak.In the classroom, piano teachers cannot well guide students' basic vocal sound skills training due to professional restrictions (Xinchao, 2020).Students can basically complete simple nursery rhyme accompaniment and playing and singing, but 
there is a problem of insufficient musical expression. Moreover, in the actual performance process, students can not give consideration to playing and singing at the same time (Huan, 2020).

The children's song accompaniment and playing and singing course requires students to have certain basic musical literacy, be able to distinguish the differences of scale, tone and rhythm, and further identify different styles of children's song music (Yao, 2021). However, the current curriculum lacks the cultivation of music core quality. In teaching, students are often only trained unilaterally (Xuelei 2021), and do not pay attention to the cultivation of rhythm, melody, musical sense, rhythmic movement and absolute pitch ability in music core quality. Therefore, students cannot show the musicality and artistry of children's songs in children's song accompaniment and playing and singing (Shasha, 2020).

\subsection{Teaching Mode and Teaching Methods}

In some pre-school teaching of higher vocational education, teachers' teaching concept of playing and singing is relatively old, which is still a traditional teaching concept, which does not meet the requirements of talent training at this stage. At the same time, it is not in line with students' learning characteristics and curriculum objectives, has less mastery of advanced teaching concepts and methods, and has insufficient understanding of preschool education posts at this stage, so it is difficult to keep pace with the times (Tian, 2021).At present, the piano course of preschool education is basically a collective teaching mode which can save teaching resources and is beneficial to the cultivation of students' interests, increasing the opportunities for students to discuss, compare and compete (Hualiang, 2020). However, because it is difficult to take into account the individual differences of students in the form of piano collective class, it is impossible for teachers to take into account every student and teach handin-hand for the learning of piano skills (Zhongsheng, 2019).

Most piano teachers majoring in preschool education in higher vocational colleges graduate from the professional Conservatory of music, with high professional quality and professional piano teaching (Yun, 2019).However, teachers do not have enough understanding of the discipline characteristics of preschool education and the positioning of piano nursery rhyme accompaniment and singing courses, and do not know the professional needs of this major, The orientation and goal of the course are not clear (Weihong, 2019). As a result, the professional piano teaching method in the Conservatory of music has been continued in the children's song accompaniment and singing class, which is not conducive to the talent training of preschool education specialty, and there will be some problems, such as improper selection of teaching materials, unclear teaching objectives and so on (Jun, 2019). In addition, the teaching method is single, and most of them use the processes of playing and singing knowledge explanation, playing and singing, independent practice and teacher guidance. Although they are integrated into the teaching objectives, the classroom is not vivid, the teaching method is not flexible, and the curriculum connection is rigid, resulting in students losing interest in the curriculum and low teaching efficiency (Xiaoqin, 2020). There are no efficient teaching methods and strategies in cultivating students' comprehensive music ability (Min, 2021).

\subsection{Teaching Practice}

For a long time, the lack of learning and practice ability has always been the main factor perplexing the educational development of Higher Vocational Colleges (Rongxing, 2019). Due to the unreasonable allocation of educational resources in higher vocational colleges, the teaching of children's song playing and singing course can not carry out teaching practice in a good environment, and its teaching quality also declines, which is difficult to meet the needs of children's song playing and singing course of preschool education major to serve preschool education (Weihong, 2019).

The curriculum of children's song accompaniment and playing and singing needs to strengthen students' mastery of scale, music rhythm and other contents through continuous learning and practice. However, some higher vocational colleges ignore the importance of practical learning of children's song accompaniment and playing and singing in preschool education.

As a result, the teaching quality of children's song accompaniment and playing and singing courses for preschool education majors in some higher vocational colleges has not been significantly improved (Yao, 2021).In addition, the overall teaching time of children's song accompaniment and playing and singing course is limited, so it is difficult for most teachers to guide all students to have basic piano playing and singing ability and comprehensive music quality within the existing total teaching time, resulting in the actual teaching effect lower than the expected goal (Xinyi, 2020).

\section{CHILDREN'S SONG ACCOMPANIMENT AND PLAYING AND SINGING TRAINING STRATEGY}

In order to solve the above problems and phenomena in the curriculum and better cultivate excellent kindergarten teachers, the preschool education major in higher vocational colleges should follow the post ability orientation strategy advocated by the Ministry of Education and gradually improve the children's song accompaniment and playing and singing curriculum.In the teaching process, creative, flexible and practical teaching methods should be used to stimulate students' interest in learning, so as to improve their social competitiveness (Yu, 2020).

\subsection{Adjusting Training Objectives}

In 2018, China's Ministry of Education proposed that the training goal of applied talents is to mainly cultivate applied talents, and pay attention to practicality in teaching and curriculum, as well as serving local economic development 
(China's Ministry of Education, 2018). The talent training objectives of applied preschool education should be set from the actual development of the region, based on the social development and school running characteristics of the region, and according to the requirements of local social development, set the applied talent training objectives that meet the local needs (Lifeng, 2021). Piano curriculum should focus on cultivating students' comprehensive ability of children's song accompaniment and playing and singing, so as to meet the needs of future preschool teachers' posts, and make the students trained by preschool education specialty perfectly connect with preschool education posts (Xiaoqin, 2020). The output oriented education model is based on OBE (output based education), and the training goal is the learning achievement that students should finally achieve (Liying\&Chen, 2021). Talent positioning should be carried out through the job needs of kindergartens. Only by clarifying the talent positioning can teaching objectives be formulated. When teaching courses, teachers should guide students to clarify job needs and improve training objectives (she Hualiang, 2020). In the teaching process, teachers should position the curriculum, deal with the relationship between technical teaching and art teaching, guide students to analyze children's psychological characteristics, children's song characteristics and song melody while teaching playing and singing technology, and enhance students'performance of playing and singing. On the basis of cultivating students' ability to play and sing, teachers should focus on cultivating students to express songs with playing and singing ability to interact with children in playing and singing (Yu, 2020).

\subsection{Improve the Level of Curriculum Aesthetic Education}

In 2020, according to the purpose of the "improvement of Aesthetic Education Teaching and students' aesthetic and humanistic quality" proposed by the Ministry of Education of China, it further expanded the basic position of aesthetic education in the whole education system (Ministry of Education of China, 2020). As a required course for preschool education, children's song accompaniment and playing and singing course is not only an important part of music education, but also one of the effective ways to implement music aesthetic education, and a concrete embodiment of the value goal of aesthetic education in vocational colleges (Yumeng, 2021).

Aesthetic education can be integrated into the compilation and playing and singing of children's songs, so that students can understand children from music, explore the rules of children's life, experience children's life and learning, so as to maintain a positive emotion and correct attitude, consolidate the foundation of students'music aesthetic(Qianyu, 2018).Cultivate students to carry out music aesthetic education by feeling the internal performance of music, and emphasize the internal emotional experience(Huan, 2020). At the same time, teachers are supposed to consciously stimulate students' aesthetic imagination, enhance aesthetic experience, so that students can better feel music and understand music (Xia, 2019).

The learning process of children's song accompaniment and playing and singing course is not simply finger skills training. It should start from musical performance and aesthetic needs, guide students to perceive music elements, externalize emotions and thoughts, and perform through playing and singing, so as to improve students' musical aesthetic performance (Xiaoqin, 2020).

\subsection{Adjust Teaching Methods}

All higher vocational colleges should improve the teaching quality of teachers, optimize the talent training mode, and really exercise students' innovative ability, so that students majoring in preschool education can quickly realize career shaping in kindergartens, so that students can analyze and deal with problems as a whole from the perspective of children, so as to improve their educational ability (Lifeng, 2021).Teachers should pay more attention to the students' play of subjectivity in the classroom. In addition to teaching the students' singing knowledge, they should also add some rhythm and performance teaching (Yun, 2019).

Teachers should update their ideas, seek efficient and practical teaching modes and methods, so that students can develop and improve in music creativity, perception, imagination and other aspects(Weijie, 2020). In the traditional teaching mode, music teaching method is an independent course. It is difficult for students to effectively rely on and integrate the specific situation of the kindergarten teaching of playing and singing in the process of receiving music pedagogy teaching and training (Xueying, 2020).

By integrating western music teaching method into the teaching of children's song accompaniment and playing and singing courses, teaching can be carried out by the combination of group teaching and group teaching, theoretical teaching can be carried out collectively, and practice can be carried out by in the form of group(Tian, 2021), so that students can master the entry point and skills of using various music teaching methods in playing and singing teaching, so as to effectively achieve the practical teaching goal of music teaching method subjects (Hui, 2020b).

The knowledge and skills of music teaching method are integrated into the teaching content system with the theme. Through related teaching, students really have the ability to organically use various new teaching methods to carry out playing and singing teaching (Wang, 2019). Teachers can also create a variety of teaching situations, simulate the working environment of the kindergarten, so that students can integrate into the kindergarten work situation, carry out rich teaching, and fully experience the teaching experience of preschool teachers (Xuefan, 2019).

\subsection{Strengthen Students' Practice}


In the teaching of children's song accompaniment and playing and singing, teachers should pay attention to the cultivation of students' music perception ability, so as to improve students' aesthetic ability, enhance students' music sensitivity with repeated practice, optimize teaching content in combination with practical teaching, promote the integration of music knowledge, and help students master music knowledge more comprehensively (Tian, 2021). Teachers add music activities in the actual classroom to allow students to play independently and encourage students to create independently. Teachers give corresponding creative guidance to deepen the understanding of the background of children's songs, experience the connotation of children'ssongs and make the creation meaningful (Xueying, 2020). Such teaching activities not only increase the interaction and communication between teachers and students, but also create a good classroom atmosphere for students, Enrich students' experience in classroom practice (Debei, 2019).

However, many students majoring in preschool education can't give full play to their children's song accompaniment and singing ability effectively due to psychological quality and other reasons in the process of playing and singing examination or teaching (Xinchao, 2020).

Teachers can let students compose and perform children's songs in groups, so as to strengthen students' psychological quality and improve students' mutual assistance ability in classroom learning (Yao, 2021).Teachers add the music rhythm design in the classroom to guide students to make natural responses to music, which can not only relax students' body and mind but also experience the changes of music, let the body rhythm feel the music, and finally feedback to the play and singing performance ((Dayong, 2019).In order to strengthen the students 'psychological quality exercise, the school can open some play and singing competitions, to promote learning, improve the students' importance to learning (Zhongsheng, 2019).During the student internship, students can be organized to carry out singing teaching observation and internship in the kindergarten, so that students can really feel the teaching of children's songs on the platform, expand the depth and breadth of practical activities, and enhance the students' independent thinking ability through the teaching environment of the kindergarten (Rongxing, 2019).

\section{CONCLUSION}

With the society's attention to aesthetic education, schools have higher and higher requirements for the music quality of kindergarten teachers. Preschool education students in higher vocational colleges are facing good development opportunities and severe challenges. Therefore, they must have clear learning objectives and rich practical experience in order to meet the needs of employment. Therefore, piano instructors in higher vocational colleges should also clarify the talent training objectives, focus on cultivating comprehensive music quality, strengthen the construction and cultivate excellent students' practice, so as to meet the needs of social high-quality basic education.

\section{REFERENCE}

[1]. Dayong, C. (2019). On the teaching of children's song playing and singing in preschool education major of Secondary vocational school. Northern Music, 1002-767X, 185-186.

[2]. Debei, L. (2019). Playing and singing training strategies for preschool education major. Northern Music, 1002-767X, 155-156.

[3]. Fan, F. (2021). On the cultivation of playing and singing ability in the teaching of preschool Education in colleges and universities -Taking keyboard and Children's Song Accompaniment as an example. New Silk Road Horizon, 1671-9670, 119-120.

[4]. Fang, Z. (2020). Exploration of piano Playing and Singing Practice in preschool Education of higher vocational Colleges. Education Practice, 04, 251.

[5]. Hualiang, S. (2020). Reflection on piano children's Song playing and singing course in Preschool Education major of Higher Vocational Education. Modern Music, 1007-2233, 51-52.

[6]. Huan, X. (2020). Exploration on the reform of children's song playing and singing teaching in Higher Vocational Education -Taking vocal music course as an example. Song of the Yellow River, 1004-6127, 68-69.

[7]. Hui, C. (2020a). Research on the cultivation strategy of children's Song playing and singing ability of Students majoring in Preschool Education in Higher Vocational Colleges. Song of the Yellow River, 1004-6127, 80-81. https://doi.org/10.19340/j.cnki.hhzs.2020.10.043

[8]. Hui, C. (2020b). Thinking on the Reform of children's Song Playing and Singing Teaching in piano Collective Lesson. The North Music, 4-5.

[9]. Jun, W. (2019). The present situation and improvement strategy of children's song Playing in preschool Education major in colleges and universities. Song of the Yellow River, 1004-6127, 2.

[10]. Lifeng, F. (2021). Reform and practice of talents training mode for preschool Education specialty in application-oriented universities. Examination Questions and Research, 1673-1301, 41-42.

[11]. Min, S. (2021). On the cultivation of children's song playing and singing ability of students in Higher Vocational preschool Education. Art Panorama, 2096-0905, 72-73.

[12]. Mingru, L. (2021). Research on the problems and relevant countermeasures in the teaching of children's songs playing and singing. Writers and Artists of China, 1007-8932, 95-96.

[13]. Nong Liying;Liao Chen. (2021). Practice research on pre-service training of preschool Education specialty based on OBE. Journal of Changchun Normal University, 2095-7602, 160-164.

[14]. Qianyu, H. (2018). Research on the importance of children's song playing and singing ability training to preschool music teaching. Northen Music, 1002-767X, 203-204.

[15]. Rongxing, T. (2019). On the Current Situation of Music Teaching in Preschool Education of Higher Vocational Education. The Guide of Science \& Education, 1674-6813, 42-43. https://doi.org/10.16400/j.cnki.kjdkz.2019.11.021

[16]. Ruofei, L. (2020). Research on the existing problems and optimization strategies of children's song playing and singing teaching in preschool art education major. Northern Music Music, 1002-767X, 181-182.

[17]. Shasha, P. (2020). Research on Online Teaching of Piano Play and Singing Collect Course in Pre-school Education Major of Colleges and Universities. Evaluation of Art, 100-102.

[18]. Tian, T. (2021). Analysis of secondary vocational preschool education students children's singing ability training path. Modern Vocational Education, 2096-0603, 42-43.

[19]. Tonghui, L. (2019). Practical Exploration on Teaching of Impromptu Accompaniment and Singing of Children's Songs under the Background of Teachers' Professional Certifi cation - Take Department of Preschool Education of Shantou Polytechnic for Example. Journal of Southern Vocational Education, 2095-073X, 93-96. 
[20]. Wang, L. L. (2019). Reform and practice innovation of piano teaching in pre-school education. North Music, 1002-767X, 199200.

[21]. Weihong, G. (2019). Problems and solutions of children's songs playing and singing in preschool education majors. Northen Music, 1002-767X, 140-141.

[22]. Weijie, X. (2020). Strategies for cultivating children's singing ability in preschool education of Higher Vocational Education. Song of the Yellow River, 1004-6127, 110-111. https://doi.org/10.19340/j.cnki.hhzs.2020.19.053

[23]. Xia, P. (2019). On the training of children's songs playing and singing skills of secondary vocational students under the background of skills competition. Ability and Wisdom, 2017(1673-0208), 119.

[24]. Xiaoqin, H. (2020). Research on children's song playing and singing teaching in pre-school Education Specialty under post Competence-oriented. Journal of Jiamusi Vocational Institute, 2095-9052, 117-118

[25]. Xinchao, H. (2020). Thinking on reform of children's song playing and singing teaching in preschool Education specialty of Higher Vocational Colleges. Culture Industry, 1674-3520, 156157.

[26]. Xinyi, Z. (2020). Analysis on the cultivation of children's song playing and singing ability of students majoring in preschool Education in Higher Vocational Colleges. PR Magazine, 16730445, 40-42. https://doi.org/10.16645/j.cnki.cn11$5281 / \mathrm{c} .2020 .04 .022$

[27]. Xuanxuan, C. (2021). The teaching of children's songs under the background of "National Examination" for students majoring in preschool education. The Artists, 1004-1206, 92-93.

[28]. Xuefan, Y. (2019). Teaching research on playing and singing of children's songs in secondary vocational kindergarten teachers based on post ability. Guangdong Vocational Technical Education and Research, 1674-859X, 119-122.

[29]. Xuelei, C. (2021). The penetration of children's songs in piano teaching. Home Drama, 1007-0125, 122-123.
[30]. Xueying, H. (2020). On the modular construction of playing and singing courses for preschool education majors in higher vocational colleges. Song of the Yellow River, 1004-6127, 101. https://doi.org/10.19340/j.cnki.hhzs.2020.12.096

[31]. Yao, X. (2021). Practice research on the layered teaching of children's song playing and singing in preschool Education specialty of Higher Vocational Education. Journal of Jilin TV \& Radio University, 1008-7508, 40-42.

[32]. Yu, C. (2020). On the cultivation of children's song playing and singing ability of students in Higher Vocational preschool Education. The Farmers Consultant, 1003-5494, 246.

[33]. Yuan, W. (2017). Research on the teaching and Learning of nursery rhymes based on post Ability demand.

[34]. Yumeng, L. (2021). Study on aesthetic education value of piano course in Preschool Education Specialty. Home Drama, 1007$0125,181-182$.

[35]. Yun, J. (2019). Cultivation of children's songs playing and singing ability of preschool education major students. Song of the Yellow River, 1004-6127, 98.

[36]. Yuzhe, G. (2020). Practice and Exploration ofOnline Teaching of Playing and Singing Skills in Pre-school Education. Journal of Qiqihar Junior Teachers'College, 1009-3958, 108-109. https://doi.org/10.16322/j.cnki.23-1534/z.2020.05.037

[37]. Zhongsheng, W. (2019). Discussion on teaching Content reform practice of "Piano Foundation and Children's Song Playing" course. Song of the Yellow River, 1004-6127, 91-92.

\section{SPONSORSHIP}

This study is sponsored by the Humanities and Social Sciences Youth Project of Hubei Provincial Department of Education (project number: 21Q149) 